\title{
Erratum to: Differential influence of QTL linked to Fusarium head blight, Fusarium-damaged kernel, deoxynivalenol contents and associated morphological traits in a Frontana-derived wheat population
}

\section{Ágnes Szabó-Hevér · Szabolcs Lehoczki-Krsjak • \\ Mónika Varga • László Purnhauser • \\ János Pauk · Csaba Lantos · Ákos Mesterházy}

Published online: 19 August 2014

(C) Springer Science+Business Media Dordrecht 2014

Erratum to: Euphytica

DOI 10.1007/s10681-014-1124-2

Due to an unfortunate turn of events, the first- and surnames of all authors were transposed in the original publication. The correct representation of the authors and their affiliations are listed above and below and should be treated as definitive by the reader. 